\title{
The Relationship between Filaments, Killing and Restoration in Irradiated Escherichia coli Strain B
}

\author{
By DIANA BROWN AND N. E. GILLIES \\ Department of Biology as Applied to Medicine, \\ The Middlesex Hospital Medical School, London, W. I
}

(Accepted for publication 8 December 197I)

SUMMARY

The morphology of normal and 5-bromouracil (5-BU) containing Escherichia coli strain B was examined after exposure of the bacteria to X-rays (under aerobic and anoxic conditions) and to ultraviolet light (u.v.). The majority of filaments which developed after irradiation either originated a microcolony or disintegrated. Post-irradiation incubation with chloramphenicol (CMP) restored the ability of some of the bacteria to originate viable colonies by suppressing filament formation, particularly in the case of normal thymine-containing bacteria. CMP also prevented the disintegration of filaments, provided it was applied before they reached a critical length. This was particularly evident in 5-BU-containing bacteria. It is suggested that incubation with CMP may allow wall synthesis to proceed in the absence of protein synthesis, thereby enabling thickening of the wall to take place, so that normal division can resume on removal of the CMP.

\section{INTRODUCTION}

Escherichia coli strain B is characterized by a high radiation sensitivity associated with the growth of many bacteria into long non-septate filaments (Witkin, 1947; Alper, 1957; Van de Putte, Westenbroek \& Rorsch, 1963; Adler \& Hardigree, 1965). This apparent marked radiation sensitivity of the mechanism controlling division is due to a genetic deficiency at the $f i l$ locus in this strain. Extensive restoration of the colony-forming ability of $E$. coli B is effected by many post-irradiation treatments, including holding in suspension before plating (Roberts \& Aldous, 1949), incubation on minimal medium (Alper \& Gillies, 1960), and temporary incubation under conditions which limit protein synthesis (Gillies \& Alper, 1959; Gillies, I96I). All of these probably act by slowing growth and allowing time for recovery of the division mechanism to take place. Incubation on nutrient medium with pantoyl lactone (Adler \& Hardigree, 1965; Kantor \& Deering, 1966; Bazill, 1967), which promotes the formation of cross septa, and incubation at temperatures above the optimum for growth (Anderson, I95I; Buzzell, I956; Adler \& Hardigree, 1965) also effect restoration.

To learn more about the relationship between killing, restoration and filament formation we have examined the morphology of Escherichia coli $\mathrm{B}$ by light microscopy after exposure of the bacteria to u.v. or to X-rays under conditions, during or after irradiation, which are known to modify survival. These were as follows: (i) aerobic and anaerobic conditions during X-irradiation; (ii) sensitization by incorporation of 5-BU into the bacterial DNA (Greer, 1960; Kaplan, Smith \& Tomlin, 1962); (iii) incubation of irradiated thymine and 5-BU-containing bacteria on nutrient medium containing CMP. Gillies (I966) found a relatively greater increase in survival after this treatment of bacteria-containing 5 -BU rather than thymine; (iv) incubation of u.v.-irradiated bacteria for a short interval on nutrient 
medium before treating with CMP, which further enhances the increase in survival effected by CMP (Gillies \& Alper, 1959); (v) incubation after u.v. irradiation at $20^{\circ}$, which reduces survival (Alper \& Gillies, I960), and at $45^{\circ}$, which increases survival (Anderson, I95I ; Buzzell, I956; Alder \& Hardigree, I965) compared to that at $37^{\circ}$.

Strain

\section{METHODS}

The strain Escherichia coli B was the same as that used previously by Alper \& Gillies (I958).

\section{Media}

The bacteria were grown for $15 \mathrm{~h}$ in minimal medium and then diluted to $2 \times 10^{6}$ bacteria/ $\mathrm{ml}$ in a defined medium (Gillies, I966) containing sulphanilamide (0.15\%) and either thymine ( $50 \mu \mathrm{g} / \mathrm{ml})$ or 5 -BU $(75 \mu \mathrm{g} / \mathrm{ml})$. A $20 \mathrm{ml}$ portion of culture in a $100 \mathrm{ml}$ bottle was grown for $6 \mathrm{~h}$ at $37^{\circ}$ on an angled turntable, by which time the concentration was about $2 \times 10^{8}$ bacteria $/ \mathrm{ml}$.

\section{Preparation of bacteria for irradiation}

The cultures were centrifuged, washed twice in $0.067 \mathrm{M}$-phosphate buffer $(\mathrm{pH} \mathrm{7 \cdot 2)}$ and resuspended in fresh buffer at a concentration of about $10^{7}$ bacteria $/ \mathrm{ml}$ for irradiation. The method of irradiation with u.v. was as described previously (Gillies, I966). Unfiltered X-rays were obtained from a Marconi $250 \mathrm{kV}$ C.P. therapy machine operated at $230 \mathrm{kVp}$ and I $5 \mathrm{~mA}$. The dose rate in the irradiation vessels (Alper, 1955), as determined by ferrous sulphate dosimetry, was $I \cdot 8 \mathrm{krads} / \mathrm{min}$. Either oxygen or oxygen-free nitrogen was bubbled through the vessels before and during the irradiations, which were performed at room temperature.

\section{Treatment of bacteria after irradiation}

Microscopic examination. The method of Alper (1957) was used. Small volumes (I $\mu \mathrm{l}$ ) of unirradiated or irradiated suspensions were spread on pieces of 'Cellophan' (I3 $\times$ I $3 \mathrm{~mm})$ lying on the surface of Oxoid Blood Agar Base. After the Cellophan pieces had dried the plates were incubated at the required temperature. At intervals, a piece of Cellophan was lifted from a plate and fixed on a microscope slide with a drop of chrome alum gelatin solution. The slides were dried at $37^{\circ}$, heat-fixed and stained with $1 \%$ aqueous crystal violet. Approximately 200 to 300 bacteria were examined on each slide under the light microscope and allocated to one of the following categories: (i) single bacteria; (ii) colonies, i.e. two or more bacteria, including colonies containing filaments as well as normal length bacteria (Fig. I $a$ ); (iii) filaments, i.e. single bacteria greater than three times normal length (Fig. I b); (iv) ghosts, i.e. filaments which had grown to a certain length and then had disintegrated (only the faintly staining remains of the cells could be seen (Fig. I $c$ ) - they appeared to be the same as those described by Gates, I933).

Colony counts. Appropriate dilutions were seeded on Cellophan carriers as previously described (Alper \& Gillies, 1958) and visible colonies counted after incubation overnight at $37^{\circ}$ on Oxoid Blood Agar Base. Bacteria were exposed to CMP by incorporating it into the medium (at $5 \mu \mathrm{g} / \mathrm{ml}$ ) on which the Cellophans were lying. Treatment was stopped by transferring the Cellophan carriers to plates of warm medium containing no inhibitor. 

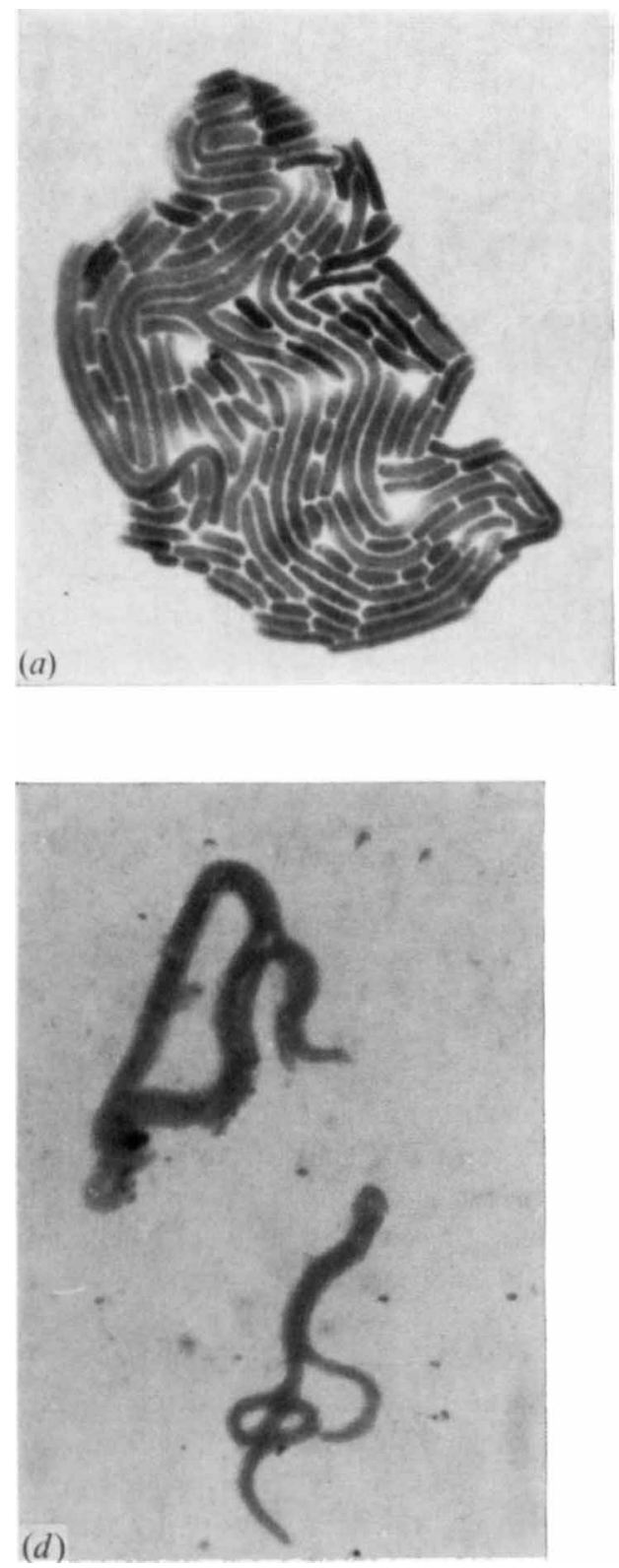
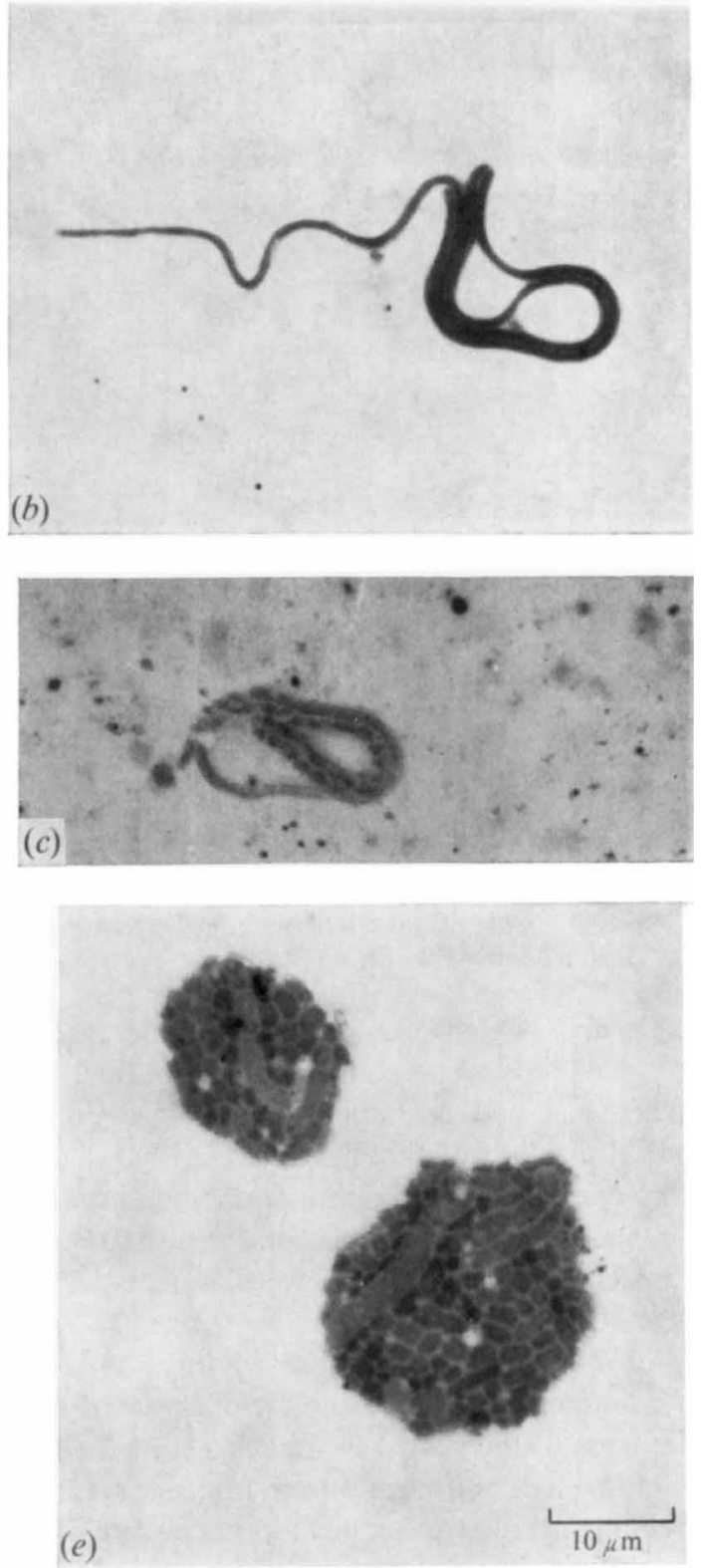

Fig. I. (a) Large microcolony containing normal and filamentous bacteria. (b) Filament. (c) Disintegrating filament or 'ghost'. (d) Bacteria incubated at $20^{\circ}$ after u.v. irradiation. (e) Microcolonies grown from bacteria incubated at $45^{\circ}$ after u.v. irradiation.

\section{RESULTS}

Thymine-containing Escherichia coli strain $\mathrm{B}$

The rate of division of unirradiated bacteria is illustrated in Fig. 2. Very few formed filaments, and after $5 \mathrm{~h}$ the majority of bacteria had divided to originate microcolonies. After the exposure to II.5 ergs $/ \mathrm{mm}^{2}$ of u.v. there was a marked lag in the division of those 


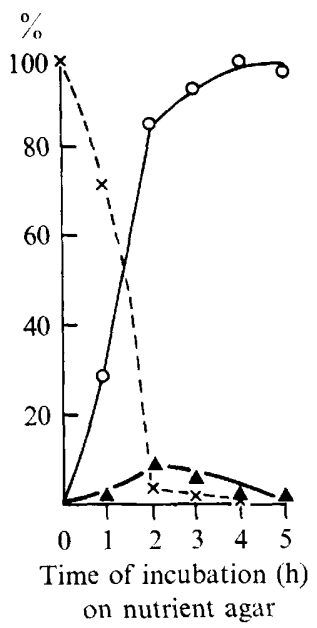

Fig. 2

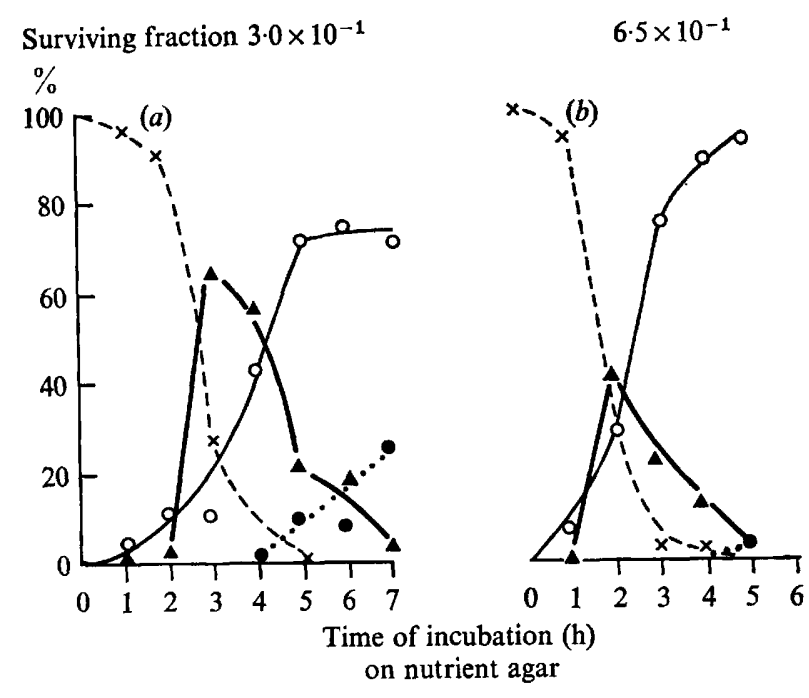

Fig. 3

Fig. 2. Growth and division of unirradiated Escherichia coli strain B (logarithmic phase) on nutrient agar. Bacteria were grown before plating in sulphanilamide medium containing thymine ( $150 \mu \mathrm{g} / \mathrm{ml})$. $\times---\times$, Cells; $\Delta-\mathbf{\Delta}$, filaments; $\mathrm{O}-\mathrm{O}$, colonies.

Fig. 3. Growth and division of Escherichia coli strain B (logarithmic phase) after exposure to II $5 \mathrm{ergs} / \mathrm{mm}^{2}$ ultraviolet radiation. Bacteria were grown before irradiation in sulphanilamide medium containing thymine. After irradiation bacteria were plated on $(a)$ nutrient agar, $(b)$ nutrient agar $+\mathrm{CMP}(5 \mu \mathrm{g} / \mathrm{ml})$ for $2 \mathrm{~h}$ before transfer to nutrient agar (time o). $\times \cdots \times$, Cells; $\boldsymbol{\Delta}-\boldsymbol{\Delta}$, filaments; $\mathrm{O}-\mathrm{O}$, colonies; $\mathrm{O}$... ghosts.

single cells which eventually were able to originate microcolonies (Fig. $3 a$ ). Also, about $60 \%$ of the bacteria did not divide but grew into filaments. After $8 \mathrm{~h}$ incubation few filaments remained, and approximately $30 \%$ of the population consisted of ghosts, indicating that about half of the filaments had lysed. At least one cell of normal length was formed from each of the remaining filaments and this was sufficient to originate a microcolony. If the u.v.-irradiated bacteria were incubated on CMP-containing nutrient agar for $2 \mathrm{~h}$ before transfer to nutrient agar, fewer filaments were formed but, more strikingly, very few ghosts were observed (Fig. $3 b$ ).

After exposure to $6 \mathrm{krads}$ of X-rays under anoxia, about $60 \%$ of the bacteria developed into filaments, but the majority of these originated microcolonies, and less than $10 \%$ of the filaments disintegrated into ghosts (Fig. $4 a$ ). After treatment with CMP very few filaments were formed, and ghosts were not observed (Fig. $4 b$ ).

Filaments also developed after exposure of the bacteria to 6 krads of X-rays under aerobic conditions, but fewer than after u.v. or anoxic X-irradiation, despite the fact that the surviving fraction was lower after aerobic X-irradiation. About one-third of the filaments disintegrated into ghosts while the remainder originated microcolonies (Fig. 5a). After $2 \mathrm{~h}$ treatment with CMP (Fig. $5 b$ ) very few filaments developed and consequently few ghosts were detected. Despite the marked suppression of filament growth by chloramphenicol, however, little restoration in terms of viable colonies occurred (Gillies, 1966).

\section{5-BU-containing Escherichia coli strain $\mathrm{B}$}

A substantial fraction of unirradiated bacteria which had been grown in 5-BU medium readily formed filaments when grown on nutrient agar (Fig. 6). The majority of these 


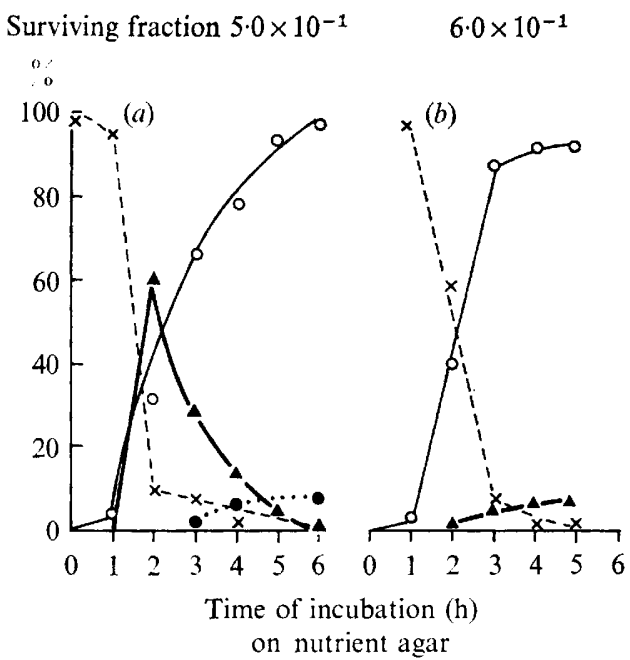

Fig. 4

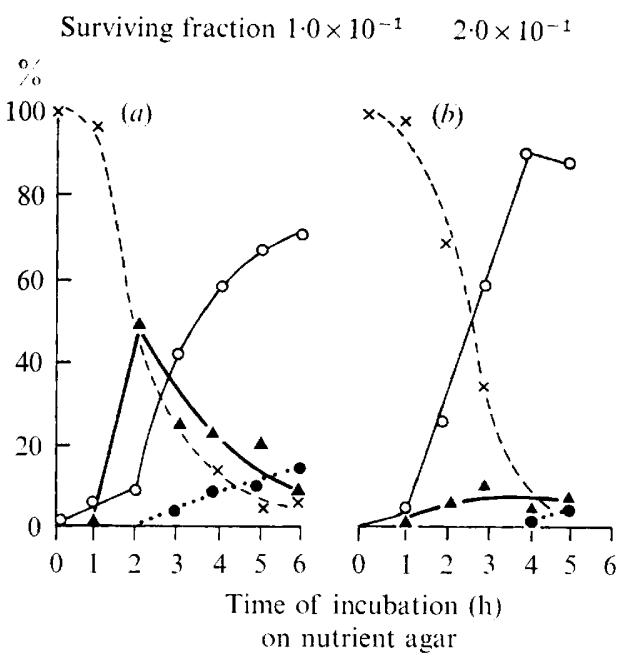

Fig. 5

Fig. 4. Growth and division of Escherichia coli strain B (logarithmic phase) after exposure to 6 krads $\mathrm{X}$-irradiation under anoxic conditions. Bacteria were grown before irradiation in sulphanilamide medium containing thymine. After irradiation bacteria were plated on (a) nutrient agar, (b) nutrient agar + CMP for $2 \mathrm{~h}$ before transfer to nutrient agar (time o). Symbols as for Fig. 3.

Fig. 5. Growth and division of Escherichia coli strain B (logarithmic phase) after exposure to 6 krads $\mathrm{X}$-irradiation under aerobic conditions. Bacteria were grown before irradiation in sulphanilamide medium containing thymine. After irradiation bacteria were plated on $(a)$ nutrient agar, $(b)$ nutrient agar + CMP for $2 \mathrm{~h}$ before transfer to nutrient agar (time o). Symbols as for Fig. 3 .

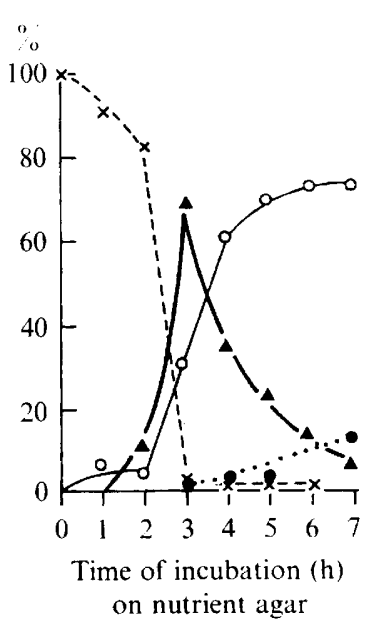

Fig. 6

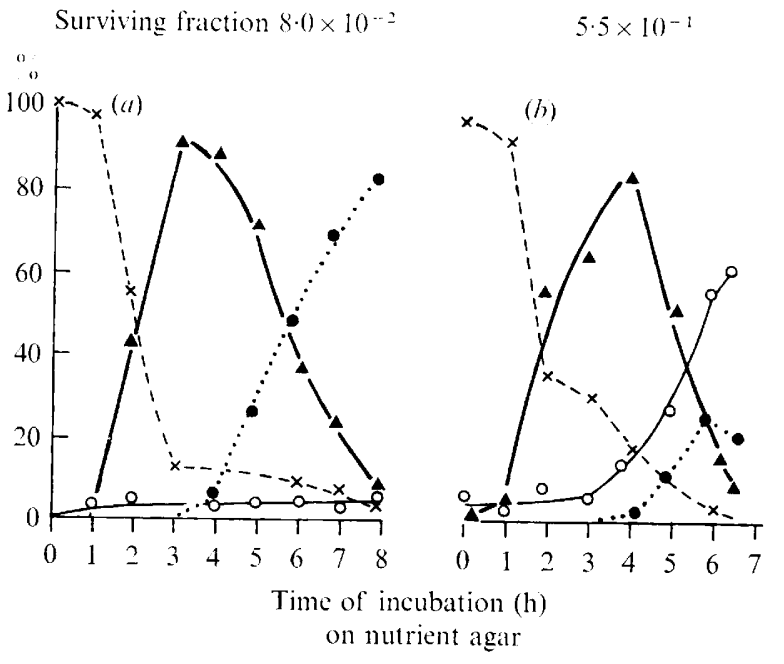

Fig. 7

Fig. 6. Growth and division of unirradiated Escherichia coli strain в (logarithmic phase) on nutrient agar. Bacteria were grown before plating in sulphanilamide medium containing 5-bromouracil (5-BU $75 \mu \mathrm{g} / \mathrm{ml}$ ). Symbols as for Fig. 3.

Fig. 7. Growth and division of Escherichia coli strain B (logarithmic phase) after exposure to I I. $5 \mathrm{ergs} / \mathrm{mm}^{2}$ ultraviolet radiation. Bacteria were grown before irradiation in sulphanilamide medium containing 5 BU. After irradiation bacteria were plated on $(a)$ nutrient agar, $(b)$ nutrient agar + CMP $(5 \mu \mathrm{g} / \mathrm{ml})$ for $2 \mathrm{~h}$ before transfer to nutrient agar (time 0$)$. Symbols as for Fig. 3 . 
Surviving fraction $3 \cdot 0 \times 10^{-2}$

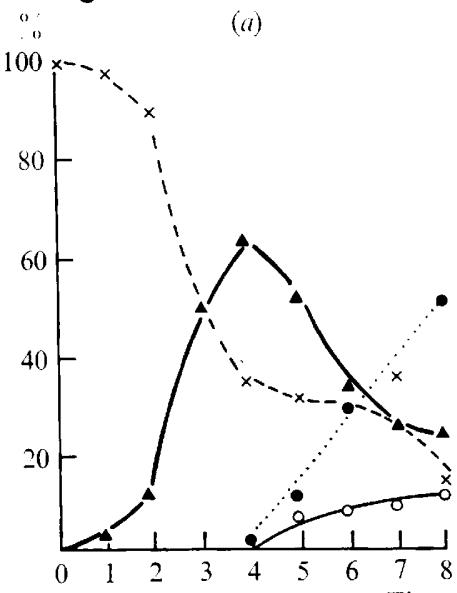

$2 \cdot 0 \times 10^{-1}$

(b)

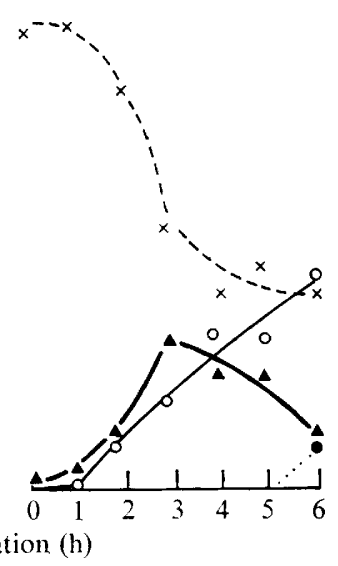

on nutrient agar

Fig. 8. Growth and division of Escherichia coli strain в (logarithmic phase) after exposure to $6 \mathrm{krads}$ $\mathrm{X}$-irradiation under aerobic conditions. Bacteria were grown before irradiation in sulphanilamide medium containing 5-BU. After irradiation bacteria were plated on $(a)$ nutrient agar, $(b)$ nutrient agar + CMP for $2 \mathrm{~h}$ before transfer to nutrient agar (time o). Symbols as for Fig. 3.

Surviving fraction $2 \cdot 5 \times 10^{-3}$

(a)

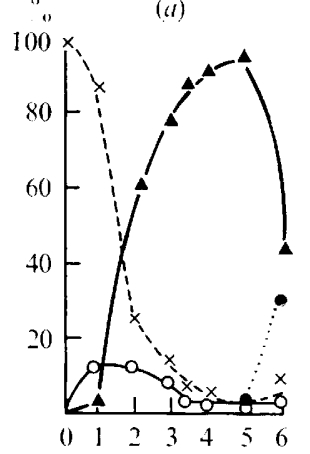

$3.0 \times 10^{-3}$

(b)

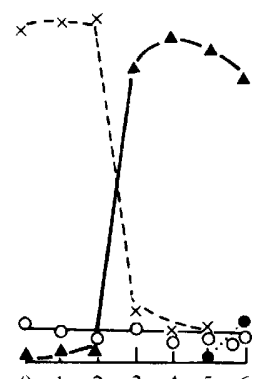

$\begin{array}{lllllllllllllllllllllll}0 & 1 & 2 & 3 & 4 & 5 & 6 & 0 & 1 & \uparrow & 3 & 4 & 5 & 6 & 7 & 0 & 1 & 2 & 3 \uparrow & 4 & 5 & 6 & 7\end{array}$

Time of incubation (h)

after irradiation

Fig. 9. Growth and division of Escherichia coli strain B (logarithmic phase) after exposure to $90 \mathrm{ergs} / \mathrm{mm}^{2}$ ultraviolet irradiation. Bacteria were grown before irradiation in sulphanilamide medium containing thymine. After irradiation (at time 0 ) the bacteria were incubated on (a) nutrient agar, $(b)$ nutrient agar+CMP for $2 \mathrm{~h}$ before transfer to nutrient agar, (c) nutrient agar for $2 \mathrm{~h}$ before transfer to nutrient agar +CMP for $2 \mathrm{~h}$ and then back to nutrient agar, $(d)$ nutrient agar for $3.5 \mathrm{~h}$ before transfer to nutrient agar + CMP for $2 \mathrm{~h}$ and then back to nutrient agar. Symbols as for Fig. 3 .

originated microcolonies, but about $10 \%$ of the original bacteria lysed and were observed as ghosts. Certainly, the viability of BU-grown cultures was always about $10 \%$ less than that of thymine-grown cultures of equal extinction, and the lower viability can be accounted for as non-viable filaments.

After exposure to II $5 \mathrm{ergs} / \mathrm{mm}^{2}$ of u.v. the majority of the 5 -BU bacteria developed into filaments and most of these disintegrated into ghosts (Fig. 7a). Very few, if any, of the filaments were able to originate microcolonies and it is concluded that the radiosensitization 
effected by 5 -BU in Escherichia coli $\mathrm{B}$ is expressed, largely, as inhibition of the cell-division mechanism. After treatment with CMP (Fig. $7 b$ ) the formation of filaments was inhibited to only a small extent but most of the filaments were able to originate microcolonies and only one third of them disintegrated. Almost identical results were obtained with 5 -BU bacteria exposed to $6 \mathrm{krads}$ of X-rays under anaerobic conditions, but after exposure to the same dose of X-rays under aerobic conditions a smaller number of bacteria developed into filaments or disintegrated into ghosts (Fig. 8a). The sizes of both of these fractions were reduced by treatment with CMP for the initial $2 \mathrm{~h}$ after irradiation (Fig. $8 b$ ).

\section{Incubation on nutrient agar before CMP treatment}

Gillies \& Alper ( I959) showed that when irradiated Escherichia coli strain B was incubated on nutrient agar for a short interval before being transferred to CMP-containing nutrient medium the increase in survival was even greater than when the bacteria were incubated on CMP medium immediately after irradiation. However, after longer periods of incubation on nutrient agar before transfer of the bacteria to medium containing CMP less restoration in colony-forming ability resulted. Data on the morphology of bacteria treated in this way (i.e. with CMP at times $0,2 \mathrm{~h}$ or $3.5 \mathrm{~h}$ after a dose of $90 \mathrm{ergs} / \mathrm{mm}^{2}$ ) are presented in Fig. 9 . As shown earlier, immediate incubation on CMP nutrient medium reduced the number of filaments which disintegrated into ghosts, without reducing to any marked extent the development of filaments. However, incubation for $2 \mathrm{~h}$ on nutrient medium before treatment with CMP substantially increased the number of filaments which was able to originate microcolonies, and at the same time prevented many filaments from disintegrating. When the bacteria was incubated for $3.5 \mathrm{~h}$ on nutrient agar before treatment with CMP the majority of filaments was not prevented from disintegrating and relatively few of them were able to originate microcolonies. Therefore, if the bacteria were incubated for too long before transfer to the CMP medium, it appeared that the filaments grew beyond a 'critical length' and lysis could not be prevented. This finding agrees with that of Kantor \& Deering (I966).

\section{The effect of incubation temperature on flament formation}

The morphology of u.v.-irradiated Escherichia coli в incubated at $20^{\circ}$ or at $45^{\circ}$ was examined, but no detailed kinetic studies were made. Incubation at $20^{\circ}$ resulted in the formation of very long bizarre filaments (Fig. I $d$ ), whereas at $45^{\circ}$ few filaments were formed and colonies developed, but the bacteria were abnormally short and stubby in appearance (Fig. I $e$ ).

\section{DISCUSSION}

Radiation-induced filaments of Escherichia coli в appeared to suffer one of two fates on incubation. Either a bacterium of normal length divided off from the filaments to originate a viable colony or the filaments disintegrated and were detected as ghosts. A small number remained as filaments. Quantitative estimates of the numbers of each occurring under the different conditions used are presented in Table $I$.

Without treatment with CMP a significant number of the filaments derived from thyminecontaining bacteria was able to originate microcolonies, but most of the filaments induced in 5-BU-containing bacteria disintegrated. The general effect of incubation with CMP was to reduce the incidence of both filaments and ghosts and to increase the number of bacteria able to originate microcolonies, even after they had grown into filaments. There were differences in response depending on the conditions under which the bacteria were grown before 
Table I. Fate of filaments of Escherichia coli $\mathrm{B}$ expressed as percentage of single cells present before irradiation

$\begin{array}{cccccc} & \text { Filaments } & \text { Ghosts } & \begin{array}{c}\text { Filaments } \\ \text { remaining }\end{array} & \begin{array}{c}\text { Colony-forming } \\ \text { filaments }\end{array} & \text { Surviving } \\ \text { Irradiation } & (a)^{*} & (b)^{*} & (c) & a-(b+c) \dagger & \text { fraction }\end{array}$

Thymine-containing bacteria not incubated with chloramphenicol

$\begin{array}{llrlll}\text { U.v. } & 64 & 26 & 3 & 35 & 3.0 \times 10^{-1} \\ \text { X-Rays }\left(\mathrm{N}_{2}\right) & 6 \mathrm{I} & 7 & \mathrm{I} & 53 & 5.0 \times 10^{-1} \\ \mathrm{X}-\text { Rays }\left(\mathrm{O}_{2}\right) & 50 & \mathrm{I} & 9 & 27 & \mathrm{I} \cdot 0 \times 10^{-1}\end{array}$

Thymine-containing bacteria incubated with chloramphenicol for $2 \mathrm{~h}$

$\begin{array}{lrrrrr}\text { u.v. } & 40 & 3 & 5 & 32 & 6.5 \times 10^{-1} \\ \text { X-Rays }\left(\mathrm{N}_{2}\right) & 6 & 0 & 6 & 0 & 6.0 \times 10^{-1} \\ \text { X-Rays }\left(\mathrm{O}_{2}\right) & 7 & 4 & 6 & 0 & 2.0 \times 10^{-1}\end{array}$

5-BU-containing bacteria not incubated with chloramphenicol

$\begin{array}{lccccc}\text { u.v. } & 9 \mathrm{I} & 84 & 7 & 0 & 8.0 \times 10^{-2} \\ \text { X-Rays }\left(\mathrm{N}_{2}\right) & 90 & 62 & 17 & 1 \mathrm{I} & 2.0 \times 10^{-1} \\ \text { X-Rays }\left(\mathrm{O}_{2}\right) & 63 & 50 & 23 & 0 & 3.0 \times 10^{-2} \\ & 5 \text {-BU-containing bacteria } & \text { incubated with chloramphenicol for } 2 \mathrm{~h} & \\ \text { u.v. } & 84 & 25 & 8 & 5 \mathrm{I} & 5.5 \times 10^{-1} \\ \text { X-Rays }\left(\mathrm{N}_{2}\right) & 73 & 20 & 20 & 33 & 5.0 \times 10^{-1} \\ \text { X-Rays }\left(\mathrm{O}_{2}\right) & 30 & 10 & 10 & 10 & 2.0 \times 10^{-1}\end{array}$

* Measured at time of maximum incidence.

$\uparrow$ The number of filaments capable of originating microcolonies was estimated by subtracting the sum of the filaments remaining and the ghosts observed from the maximum percentage of filaments.

irradiation and on the type of radiation used. For example, treatment with CMP was more effective in reducing the proportion of filaments after X-irradiation than after u.v. irradiation. Suppression of filamentation rather than prevention of filament disintegration predominated in thymine-containing bacteria, whereas the reverse was more evident in 5 -BUcontaining bacteria.

The increase in surviving fraction effected by incubation with CMP was relatively small compared to that obtained in earlier studies (Gillies \& Alper, I959; Gillies, I966) because the inhibitor was applied for only $2 \mathrm{~h}$ in the present investigation. It is difficult to correlate exactly the changes in morphology with changes in survival, but it would appear that rescue of colony-forming ability of the 5-BU-containing bacteria is due largely to the effect of CMP in preventing the disintegration of the filaments which developed, thus enabling a larger number to originate viable colonies. The results indicate that the potential for restoration is greatest under conditions where ghost formation is a maximum. Thus, even when filament formation occurred as was seen in the thymine-grown bacteria, relatively little rescue by CMP was observed because many of the filaments were able to originate colonies anyway and did not disintegrate into ghosts in the absence of CMP treatment.

Alper (1962, 1963) proposed that lethal radiation damage in Escherichia coli B could be divided into at least two classes, which she designated as Type $\mathrm{N}$ and Type $\mathrm{O}$ damage. She concluded that Type $\mathrm{N}$ damage could be rescued by treatments which included incubation with CMP. Our results suggest that filament disintegration may be the visible expression of Type $\mathrm{N}$ damage in this strain.

Adler \& Hardigree (1965) and Bazill (I967) suggested that a major type of critical lethal damage induced by radiation in Escherichia coli $\mathrm{B}$ is to the division mechanism and this therefore causes many of the bacteria to develop into filaments. However, our data indicate 
that many of these filaments are still able to originate viable macrocolonies. To account for the lysis of filaments after irradiation we suggest that some vital step in the formation of the cell wall may be inhibited so that wall synthesis is unable to keep pace with DNA, RNA and protein synthesis, with the result that the wall gradually becomes thinner and the filament eventually lyses. That the walls of filaments of $E$. coli B are different from those in normalsized bacteria was shown by Weinbaum (I966), who found that filaments induced by modified culture conditions were characterized by a lower proportion of constituents of the rigid layer (Bayer \& Anderson, 1965). There was also evidence that the wall of the filaments was discontinuous.

The primary effect of treatment with CMP is the inhibition of protein synthesis. Wall synthesis still continues under these conditions in Staphylococcus aureus (Hancock \& Park, I958; Mandelstam \& Rogers, I958) and in Bacillus cereus (Chung, I967). Thus, if the same occurs in Escherichia coli B, then treatment with CMP may enable thickening of the wall to take place, thereby repairing or by-passing the lesion, so that filaments are prevented from lysing on removal of the CMP.

Incubation at $20^{\circ}$ may enhance radiation lethality by further accentuating the imbalance between the rate of wall synthesis and the increase in bacterial mass. Shaw (I968) showed that growth of Escherichia coli ML3O at low temperature resulted in formation of many filaments in which the septa were incomplete. Thus, the effect of irradiation and subsequent incubation at $20^{\circ}$ acted to produce more and longer filaments as seen in Fig. I $(d)$. On the other hand, the stubby appearance of organisms incubated at $45^{\circ}$ may be due to the induction of more cross septa than at $37^{\circ}$, and also to a relatively faster rate of wall synthesis compared to the rates of increase in mass. This would suppress the growth of filaments and could account for the high survival of irradiated bacteria incubated at $45^{\circ}$.

Recent findings (Marshall \& Gillies, 1972) indicate that although rescue by CMP treatment is effected by suppression of radiation damage to the division mechanism in filamentous strains of Escherichia coli, it is also effective in restoring non-filamentous strains containing a mutation at the $\operatorname{exr} A$ locus.

We wish to thank Mrs J. Pelling for excellent technical assistance and The Wellcome Trust and the Medical Research Council for grants in support of this work.

\section{REFERENCES}

Adler, H. I. \& HARdigree, A. A. (1965). Post irradiation growth, division and recovery in bacteria. Radiation Research 25, 92-102.

AlPER, T. (1955). Bacteriophage as indicator in radiation chemistry. Radiation Research 2, I19-134.

AlPER, T. (1957). Observations on bacterial growth and morphology shortly after irradiation and some remarks on the oxygen effect. In Advances in Radiobiology, Proceedings of the Fifth International Conference on Radiobiology, pp. 90-96. Edited by G. C. de Hevesey, A. G. Forssberg \& J. D. Abbatt. Edinburgh: Oliver and Boyd.

AlPER, T. (1962). Evidence for two resolvable sites of action of radiation on microorganisms. In $A b h a n d-$ lungen der Deutschen Akademie der Wissenschaften zu Berlin. (Klasse für Medizin), no. I, pp. 153-I6I. Berlin: Akademie-Verlag.

AlPer, T. (1963). Lethal mutations and cell death. Physics in Medicine and Biology 8, 365-385.

AlPER, T. \& Gillies, N. E. (1958). Restoration of Escherichia coli strain B after irradiation: its dependence on sub-optimal growth conditions. Journal of General Microbiology 18, 46I-472.

AlPER, T. \& Gillies, N. E. (I960). The relationship between growth and survival after irradiation of Escherichia coli strain B and two resistant mutants. Journal of General Microbiology 22, II 3-1 28.

ANDERSON, E. H. (195I). Heat reactivation of ultraviolet inactivated bacteria. Journal of Bacteriology $6 \mathbf{r}$, 389-394. 
BAyer, M. E. \& ANDERSON, T. F. (1965). The surface structure of Escherichia coli. Proceedings of the National Academy of Sciences of the United States of America 54, 1592-1 599.

BAzILL, G. W. (1967). Lethal unbalanced growth in bacteria. Nature, London 216, 346-349.

Buzzell, A. (1956). The relationships between ultraviolet irradiation and the thermal reactivation of Escherichia coli B. Archives of Biochemistry and Biophysics 62, 97-108.

Chung, K. L. (1967). Cell wall growth of Bacillus cereus in the presence of chloramphenicol. Canadian Journal of Microbiology 13, 34I-350.

Gates, F. (1933). The reaction of individual bacterial to irradiation with ultraviolet light. Science, New York 77, 350.

GILLIES, N. E. (I96I). The use of auxotrophic mutants to study restoration in Escherichia coli B after ultraviolet irradiation. International Journal of Radiation Biology 3, 379-387.

Gillies, N. E. (1966). Restoration of 5-bromouracil sensitized Escherichia coli strain B after exposure to ionizing or ultraviolet radiation. Journal of General Microbiology 45, 97-I I I.

Gillies, N. E. \& AlPER, T. (1959). Reduction in the lethal effects of radiations on Escherichia coli в by treatment with chloramphenicol. Nature, London $\mathbf{1 8 3}, 237-238$.

GreER, S. (1960). Studies on ultraviolet irradiation of Escherichia coli containing 5-bromouracil in its DNA. Journal of General Microbiology 22, 61 8-634.

HANCOCK, R. \& PARK, J. T. (1958). Cell wall synthesis by Staphylococcus aureus in the presence of chloramphenicol. Nature, London r81, 1050-1052.

Kantor, G. C. \& DeERING, R. A. (I966). Ultraviolet radiation studies on filamentous Escherichia coli $\mathbf{B}$. Journal of Bacteriology 92, 1062-1069.

Kaplan, H. S., Smith, K. C. \& Tomlin, P. A. (1962). Effect of halogenated pyrimidines on radiosensitivity of E. coli. Radiation Research $\mathbf{1 6}, 98-\mathrm{I} 13$.

MANDElstaM, J. \& Rogers, H. J. (1958). Chloramphenicol-resistant incorporation of amino acids into staphylococci and cell wall synthesis. Nature, London $\mathbf{r 8 1}, 956-957$.

Marshall, N. J. \& Gillies, N. E. (1972). Chloramphenicol rescue of $\gamma$-irradiated lon and exr $A$ mutants of Escherichia coli. Mutation Research $\mathrm{r}_{4}, \mathrm{I3}^{-2} \mathrm{I}$.

Roberts, R. B. \& Aldous, E. (1949). Recovery from ultraviolet irradiation in Escherichia coli. Journal of Bacteriology 57, 363-375.

SHAW, M. K. (1968). Formation of filaments and synthesis of macromolecules at temperatures below the minimum for growth of Escherichia coli. Journal of Bacteriology 95, 22 I-230.

Van de Putte, P., Westenbroek, C. \& Rorsch, A. (I963). The relationship between gene-controlled radiation resistance and filament formation in Escherichia coli. Biochimica et biophysica acta 76, 247-256.

WeINBaum, G. (1966). Characteristics of cell walls from morphological variants of Escherichia coli. Journal of General Microbiology 42, 83-92.

WITKIn, E. M. (I947). Genetics of resistance to radiation in Escherichia coli. Genetics 32, 22 I-248. 